\title{
Not so standard anymore? Employment duality in Germany
}

\author{
Werner Eichhorst $\cdot$ Verena Tobsch
}

Published online: 17 June 2015

(C) Institut für Arbeitsmarkt- und Berufsforschung 2015

\begin{abstract}
This paper gives an overview of the transformation of the German labour market since the mid-1990s with a special focus on the changing patterns of labour market segmentation or 'dualisation' of employment in Germany. While labour market duality in Germany can partially be attributed to labour market reforms promoting, in particular, non-standard forms of employment and allowing for an expansion of low pay, structural changes in the economy as well as strategic choices by employers and social partners also play a prominent role. Our main argument is that the liberalization of non-standard contracts has contributed to the expansion of overall labour market inclusion and job growth in Germany and that at least some forms of non-standard work provide stepping stones into permanent regular jobs. Atypical contracts do not necessarily undermine the dominance of standard employment relationships and job quality in this primary segment but rather form a
\end{abstract}

The authors are grateful to the ILO for research support in the context of a comparative project on labour market segmentation. We would also like to thank participants of a research workshops on labour market segmentation held at the ILO on 10-11 December 2012 as well as ILO colleagues for comments on earlier versions, in particular Sandrine Cazes, as well as participants to the discussion at IAB, Nuremberg, Germany, on 14 February 2014, especially Karen Anderson. An earlier version of this study is available as IZA Discussion Paper 7609 and ILO Employment Working Paper145.

\footnotetext{
W. Eichhorst $(\square)$

Institute for the Study of Labor (IZA),

53072 P.O. Box 7240, Bonn, Germany

e-mail: Eichhorst@iza.org

V. Tobsch

INES,

Berlin, Germany
}

supplementary part of employment in sectors and occupations that depend on more flexible and maybe cheaper forms of labour.

Keywords Germany · Labour market reforms · Dualisation $\cdot$ Non-standard work

JEL codes $\mathrm{J} 21 \cdot \mathrm{J} 31 \cdot \mathrm{J} 42$

\section{Vom Normalarbeitsverhältnis zu atypischen Verträgen? Die Dualisierung des deutschen Arbeitsmarktes}

Zusammenfassung Dieser Beitrag gibt einen Überblick über den Wandel des deutschen Arbeitsmarktes seit Mitte der 90er Jahre, wobei der Fokus auf der Entwicklung der Arbeitsmarktsegmentierung oder der „Dualisierung“ der Beschäftigungsverhältnisse in Deutschland liegt. Während die Dualisierung des deutschen Arbeitsmarktes teilweise auf Arbeitsmarktreformen, die vor allem verschiedene Arten von atypischer Beschäftigung und die Verbreitung von Niedriglohn fördern, zurückgeführt werden kann, spielen ebenso strukturelle Veränderungen in der Wirtschaft sowie strategische Entscheidungen von Arbeitgeber und Tarifpartner eine entschiedene Rolle. Unser Hauptargument ist, dass die Liberalisierung atypischer Arbeitsverträge die gesamte Arbeitsmarkintegration und das Beschäftigungswachstum in Deutschland gefördert hat und dass zumindestens einige Formen atypischer Beschäftigung ein Sprungbrett in unbefristete Normalarbeitsverträge darstellen. Atypische Arbeitsverträge müssen nicht zwingend die vorherrschende Stellung von Normalarbeitsverhältnissen und die Arbeitsplatzqualität im primären Arbeitsmarkt untergraben, sondern sie stellen eine zusätzliche Art von Beschäftigung in Branchen und Berufen dar, die auf mehr Flexibilität ausgerichtet sind. 


\section{Introduction}

Up until the mid-2000s Germany was often perceived as a country of high unemployment and medium labour force participation at best (Manow and Seils 2000). However, over the last few years, in particular in the aftermath of the Great Recession in 2008-09, this picture has changed dramatically (Rinne and Zimmermann 2011; Eichhorst 2015; Caliendo and Hogenacker 2012; Dustmann et al. 2014; Reisenbichler and Morgan 2012). This does not hold only for the perception of outside observers but also for real changes in Germany's labour market performance, which is now fundamentally different from the situation in the late 1990s and early 2000s. Yet, the origins of some of the trends that have become more apparent in recent years can be traced to then. Furthermore, and in contrast to most other developed countries that were affected heavily by the global economic crisis, Germany was able to weather the recession with neither an increase in unemployment nor a decline in the number of jobs. In fact, Germany currently shows a record level of employment significantly above the employment figures reported in earlier years. This includes both an increase in the absolute number of people in employment and an increase of the employment rate. At the same time, while standard employment has recovered somewhat since mid-2005, we see a rising share of non-standard and lowpay employment (Eichhorst and Marx 2011).

The aim of this paper is to assess the role of atypical work or non-standard employment such as fixed-term contracts, part-time work, temporary agency employment, selfemployment and low pay in the development of the German labour market. First, the paper discusses definitions and potentials driving forces of atypical employment before giving an overview of various aspects of non-standard employment in Germany. As a third step, the paper tries to explain the recent transformation of the German labour market before moving to a concluding section.

\section{Why and how atypical work matters}

Labour market segmentation is by no means a new topic for labour market research. While the concept of segmented labour markets emerged in the 1970s in the context of institutionally flexible, liberal labour markets, but also using the German case as a starting point (see Doeringer et al. 1971; Sengenberger 1987), in research and policy there is a more recent increase in the attention to the phenomenon of dualisation and dualised labour markets with a particular focus on so-called non-standard or atypical forms of employment such as fixed-term contracts, part-time work, agency work or freelance. Here, the main arguments are more institutional as continental European countries have now developed a peculiar pattern of labour market regulation that is centred around a well-protected core of permanent employees benefiting from relatively strict dismissal protection, large shares of collective bargaining coverage and full integration into social insurance. Over the last decades, this model of organizing employment has been complemented by a flexible part of the labour market after a broad movement to deregulate and to encourage the take-up of non-standard or atypical forms of employment. This pattern of labour market reforms has emerged to create a flexible margin of the labour market that is expected to facilitate job growth without questioning the institutional stability of the core of the labour market, which is supported by incumbent workers and trade unions (Boeri 2010; Palier and Thelen 2010).

While non-standard forms of work can in fact allow for the creation of additional jobs, in particular in smaller firms and service occupations, they eventually result in a welldefined secondary segment of employment where transitions to permanent or regular employment can be difficult and working conditions are less favourable as contract type, employment stability or pay deviate from the standard. This divergence is also prevalent for socio-economic groups that typically enter this secondary segment with respect to age, gender, skill level or nationality. Hence, dualisation can be seen as a strategy of institutional reform creating a secondary institutional arrangement as well as an empirical phenomenon in terms of actual employment patterns that result from the changes in rules and the interaction of employers and employees in certain parts of the labour market (Emmenegger et al. 2012). In this sense, we define dualisation as specific and institutionally driven form of labour market segmentation. Still, depending on regulatory approaches to different form of atypical work, we can also see some competition between different flexible employment options from the employer's (and employee's) perspective when deciding which type of contract to use. Hence, it is also important to study the interaction of employment options that are possible in institutional terms on the one hand and employer and employee behaviour on the other hand.

This leads to the crucial role of firms in explaining the role of non-standard employment types and factors related to structural shifts in labour demand based on skills, technology and structural change. One can argue that firms will always try to use the most flexible employment option available and the lowest wage possible to employ workers, depending on the demand and supply of labour with the required skills profile (Osterman 1987). Hence, firms hiring decisions make a strong difference in the actual relevance of atypical and low-pay work. Long-term oriented standard contracts will be more resilient in occupations where long tenure is seen as a necessary precondition for productive employment due to skill requirements and expertise, i.e. where workers are not easily replaceable. 
As labour markets are in permanent structural change due to technological progress, global economic integration and socio-demographic shifts, firms, occupations and jobs change. Over the last 2 or 3 decades this has been discussed under the labels of skill-biased technological change and routine-biased technological change which may lead to either an upgrading of the skills needed in the labour market or to a more polarised structure of jobs. In this context, the growth of low-paid and high-paid jobs at the expense of the intermediate segment is often addressed (Goos et al. 2014), but also the reliance on flexible, i.e. atypical forms of employment can grow in prominence, with non-standard jobs and low pay found predominantly in some occupations, in particular in the service sector where workers are more easily replaced.

Turning to an empirical operationalization of labour market duality, the character of non-standard or atypical work can be described along different dimensions of deviation from a 'standard' or 'typical' job. This has implications for the quality of a job in terms of perceived or actual employment stability and remuneration on the one hand and probabilities of transition to a more 'typical' job on the other hand. The distance from a standard job measured by differentials regarding employment stability and pay is therefore to be seen as one dimension of atypical work, whereas the chance of moving to a standard job is a distinct second important aspect.

However, the major dividing line for labour market segmentation in different countries is not always easy to identify as different forms of standard and non-standard employment exhibit some features of instability, limited professional perspectives, low pay or other elements of 'precariousness' that are typically influenced by the respective national pattern of regulation and employment practices. It would also be misleading to automatically identify 'good' jobs with standard contracts and to consider all non-standard contracts as 'bad' or inferior in terms of job quality.

Still, one major and quite straightforward criterion for the distinction of labour market segments, at least in the dualised labour markets of Continental Europe, is the type of employment contract. In these countries, the crucial division lies between open-ended full-time contracts, identified as 'standard employment', as the primary part of the labour market on the one hand and all other types of contracts such as fixed-term contracts, (marginal) part-time, temporary agency work or self-employment on the other. The pay dimension is also relevant and runs potentially in parallel to differences in the type of contract. Typically, some sectors are less organized in collective bargaining and therefore more prone to wage flexibility at the lower end, quite in contrast to a well-organized core. Pay is, therefore, also an alternative form of flexibility to contract type. Hence, it seems fair to say that dual labour markets are based both on the duality of standard vs. non-standard contracts and on differences in pay. To assess the extent of dualisation we can therefore take into account the working conditions of different segments of the labour market, i.e. the distance between the core and the margin, on the one hand and transition probabilities on the other hand.

\section{Main developments of the German labour market}

\subsection{The general picture}

The current situation of the German labour market cannot be understood without taking into account the major restructuring since the mid-1990. Over the last 2 decades or so, both levels and structures of employment and unemployment have changed substantially. Looking at total employment figures and the overall employment rate one can see a major increase since the mid-2000s. The German employment rate increased significantly since the middle of the last decade, reaching more than $73 \%$ in 2013 . This rate is substantially higher than the long-standing average of around $65 \%$, which was characteristic for the 1990s and early 2000s (see Fig. 1), making Germany now above the UK and in line with countries such as Denmark, Sweden, the Netherlands and Austria.

In parallel, unemployment declined dramatically since 2005, even during the crisis period 2008-09. In absolute figures, German unemployment is now less than 3 million, down from a

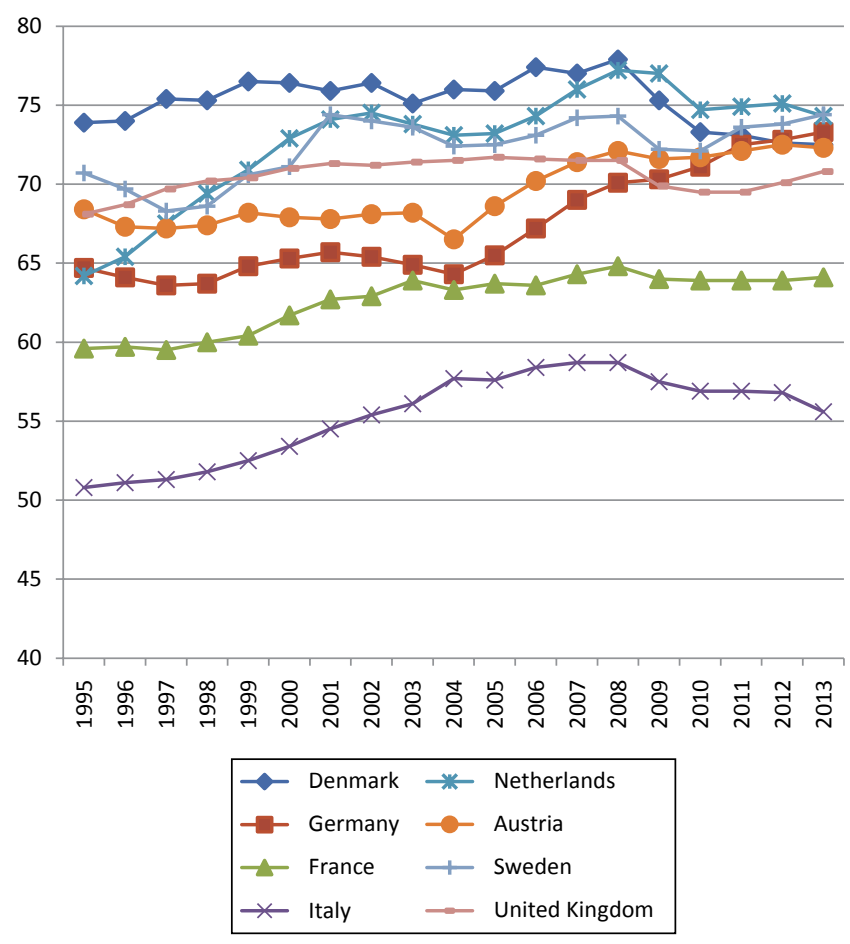

Fig. 1 Employment rates in selected European countries. (Source: Eurostat) 


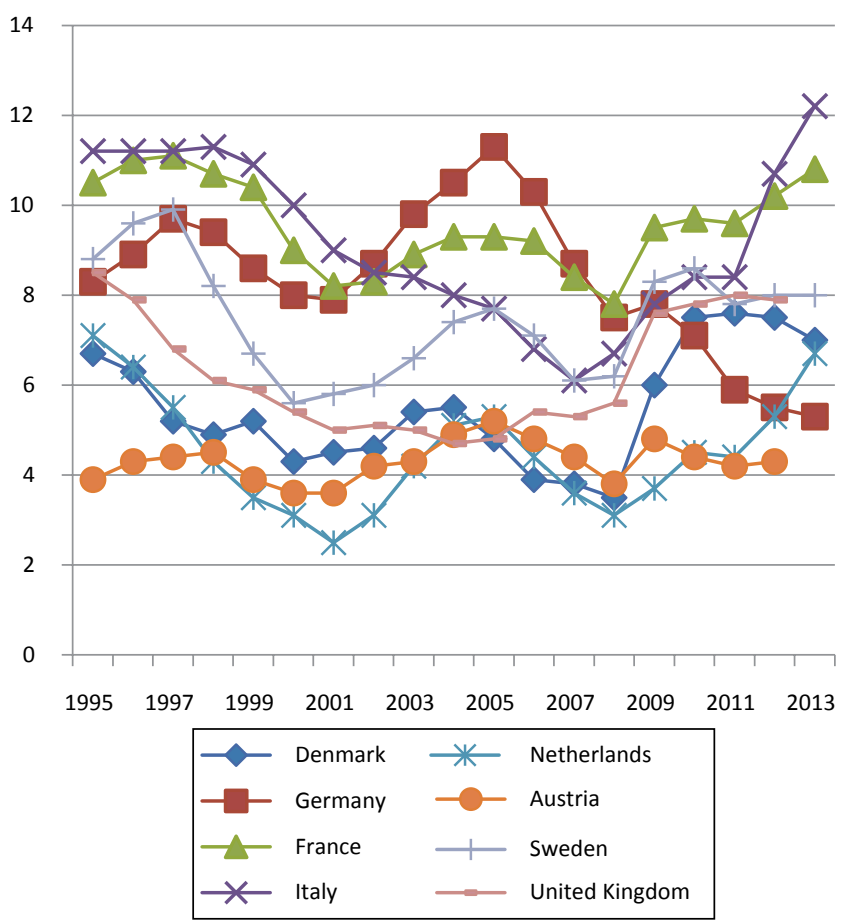

Fig. 2 Unemployment rates, 1995-2013, in selected European countries. (Source: Eurostat)

record level of 5 million in early 2005. Standardized unemployment was less than $6 \%$ of the labour force since 2011, currently one of the lowest rates in Europe (see Fig. 2). That also means that massive and apparently persistent unemployment increases in the mid-1990s and early 2000s could be reversed.
Employment rates still vary significantly between genders; however, based on headcounts, the gap between women and men has closed significantly during the 2000s. Women contributed massively to the overall increase in the employment rate, while male employment rates have been stagnant at best. Women are now much better integrated into the labour market than they were in the 1990s. However, this is not the case for full-time equivalent contracts. Here, the huge increase in different forms of part-time work, which is largely occupied by women, is related to a persistent gender gap that arises with a more substantial labour market participation of females.

The overall employment increase was also partially driven by a massive increase in the employment rate of older workers, between the ages of 55 and 64 in particular, from less than $40 \%$ in the 1990 s to about $60 \%$ most recently. Employment creation in Germany has been most beneficial to those with medium and higher educational levels where there have been some significant increases in jobs in the 2000s. At the same time, the employment rate of low-skilled people was more or less stable between 40 and $50 \%$, which is significantly below the employment levels of medium and high skilled people in Germany (see Table 1).

The group-specific pattern is most pronounced with unemployment by educational level where there is a substantially and persistently higher risk of unemployment faced by low-skilled workers. Medium skilled workers with either upper secondary schooling and/or a vocational degree have about an average risk of being unemployed while highly skilled workers (i.e. with a tertiary degree) see virtu-

Table 1 Labour market developments in Germany, 2000-2013. (Source: Eurostat)

\begin{tabular}{|c|c|c|c|c|c|c|c|c|c|c|c|c|c|c|}
\hline & 2000 & 2001 & 2002 & 2003 & 2004 & 2005 & 2006 & 2007 & 2008 & 2009 & 2010 & 2011 & 2012 & 2013 \\
\hline Employment rate (15-64 years) & 65.6 & 65.8 & 65.4 & 65.0 & 65.0 & 65.5 & 67.2 & 69.0 & 70.1 & 70.3 & 71.1 & 72.5 & 72.8 & 73.3 \\
\hline Unemployment rate (15-64 years) & 8.0 & 7.9 & 8.7 & 9.8 & 10.5 & 11.3 & 10.3 & 8.7 & 7.5 & 7.8 & 7.1 & 5.9 & 5.5 & 5.3 \\
\hline \multicolumn{15}{|c|}{ Full-time equivalent employment rates of men and women } \\
\hline In total & 65.6 & 65.8 & 65.4 & 65.0 & 65.0 & 65.5 & 67.2 & 69.0 & 70.1 & 70.3 & 71.1 & 72.5 & 72.8 & 73.3 \\
\hline Men & 72.9 & 72.8 & 71.8 & 70.9 & 70.8 & 71.3 & 72.8 & 74.7 & 75.8 & 75.4 & 76.0 & 77.3 & 77.6 & 77.7 \\
\hline Women & 58.1 & 58.7 & 58.9 & 58.9 & 59.2 & 59.6 & 61.5 & 63.2 & 64.3 & 65.2 & 66.1 & 67.7 & 68.0 & 68.8 \\
\hline \multicolumn{15}{|l|}{ Employment rates by age group } \\
\hline $15-64$ years & 65.6 & 65.8 & 65.4 & 65.0 & 65.0 & 65.5 & 67.2 & 69.0 & 70.1 & 70.3 & 71.1 & 72.5 & 72.8 & 73.3 \\
\hline $15-24$ years & 47.2 & 47.0 & 45.7 & 44.2 & 41.9 & 41.9 & 43.5 & 45.4 & 46.6 & 46.0 & 46.2 & 47.9 & 46.6 & 46.8 \\
\hline $5-54$ years & 79.3 & 79.3 & 78.7 & 77.9 & 78.1 & 77.4 & 78.8 & 80.3 & 80.9 & 80.8 & 81.5 & 82.8 & 83.2 & 83.3 \\
\hline $55-64$ years & 37.6 & 37.9 & 38.9 & 39.9 & 41.8 & 45.5 & 48.1 & 51.3 & 53.7 & 56.1 & 57.7 & 59.9 & 61.5 & 63.5 \\
\hline \multicolumn{15}{|l|}{ Employment rates by educational level } \\
\hline All levels & 65.3 & 65.7 & 65.4 & 64.9 & 64.3 & 65.5 & 67.2 & 69.0 & 70.1 & 70.3 & 71.1 & 72.5 & 72.8 & 73.3 \\
\hline $\begin{array}{l}\text { Pre-primary, primary and lower sec- } \\
\text { ondary education }\end{array}$ & 55.3 & 44.9 & 43.6 & 42.6 & 40.7 & 42.3 & 44.1 & 44.8 & 45.6 & 45.3 & 45.4 & 52.7 & 52.7 & 53.2 \\
\hline $\begin{array}{l}\text { Upper secondary and post-secondary } \\
\text { non tertiary education }\end{array}$ & 69.9 & 69.9 & 69.8 & 69.0 & 68.2 & 69.4 & 71.2 & 73.1 & 74.0 & 73.9 & 74.7 & 76.0 & 76.4 & 76.9 \\
\hline $\begin{array}{l}\text { First and second stage of tertiary } \\
\text { education }\end{array}$ & 83.0 & 83.2 & 83.0 & 82.9 & 82.6 & 82.8 & 84.2 & 85.3 & 85.7 & 86.3 & 86.7 & 87.6 & 87.6 & 87.5 \\
\hline \multicolumn{15}{|c|}{ Unemployment and long-term unemployment } \\
\hline Unemployment & 8.0 & 7.9 & 8.7 & 9.8 & 10.5 & 11.3 & 10.3 & 8.7 & 7.5 & 7.8 & 7.1 & 5.9 & 5.5 & 5.3 \\
\hline Long- term unemployment & 4.1 & 3.9 & 4.2 & 4.9 & 5.9 & 6.0 & 5.8 & 4.9 & 4.0 & 3.5 & 3.4 & 2.8 & 2.5 & 2.4 \\
\hline
\end{tabular}


ally full employment. Lack of skills is probably the most important risk of exclusion in the German labour market.

\subsection{A closer look: a structural transformation of the German employment system}

While overall employment grew, a mixed picture of the German labour market developments emerges. This can be analysed more in depth by looking at different forms of standard employment and atypical work. First, one has to note that in Germany, and somewhat in contrast to general perceptions of widespread 'precarious' employment, the number of standard employment contracts declined in the early 2000s, restabilising only in recent years. It is now only slightly below the level of the mid-1990s. At the same time, particularly in the early 2000 s, Germany experienced an increase in the number of different types of non-standard employment along with a steady decline in inactivity (see Fig. 3).

Therefore, the overall employment increase was accompanied by an increase in the share of non-standard contracts and a relative decline of standard employment only if measured as a share in total employment. Still, standard employment, defined as permanent full-time work, is the most prominent type of contract in Germany, as Fig. 3 clearly shows.
Along with the growth of low pay, this more widespread use of non-standard contracts is a major feature of labour market duality in Germany. The increase in 'atypical' jobs is partly due to sectoral change in favour of private service sector jobs, but it was also facilitated by some deregulation of legal provisions governing those jobs. Particularly striking is the massive increase in the number of part-time workers covered by social insurance and regulations that standardize working conditions. Additionally there has been an expansion of marginal part-time work with gross earnings up to 450 EUR per month. The latter can be attributed to a peculiar emerging employment pattern in some private services in reaction to the availability and expansion of the Minijob arrangement. Fixed-term contracts have remained at a medium level over recent years, with rates at about $7-8 \%$ of total employment (excluding about the same share of fixed-term apprenticeship contracts). Increased dynamism is behind the development of temporary agency work, although it is still a quite small segment of the labour market with about $2.5 \%$ of total employment. The expansion of agency work is mostly due to substantial reforms and related restructuring of companies in the manufacturing sector since the mid-2000s. Quite notably, finally, is the increase in the number of self-employed people without employees.
Fig. 3 Working-age population by employment status, 1992-2012

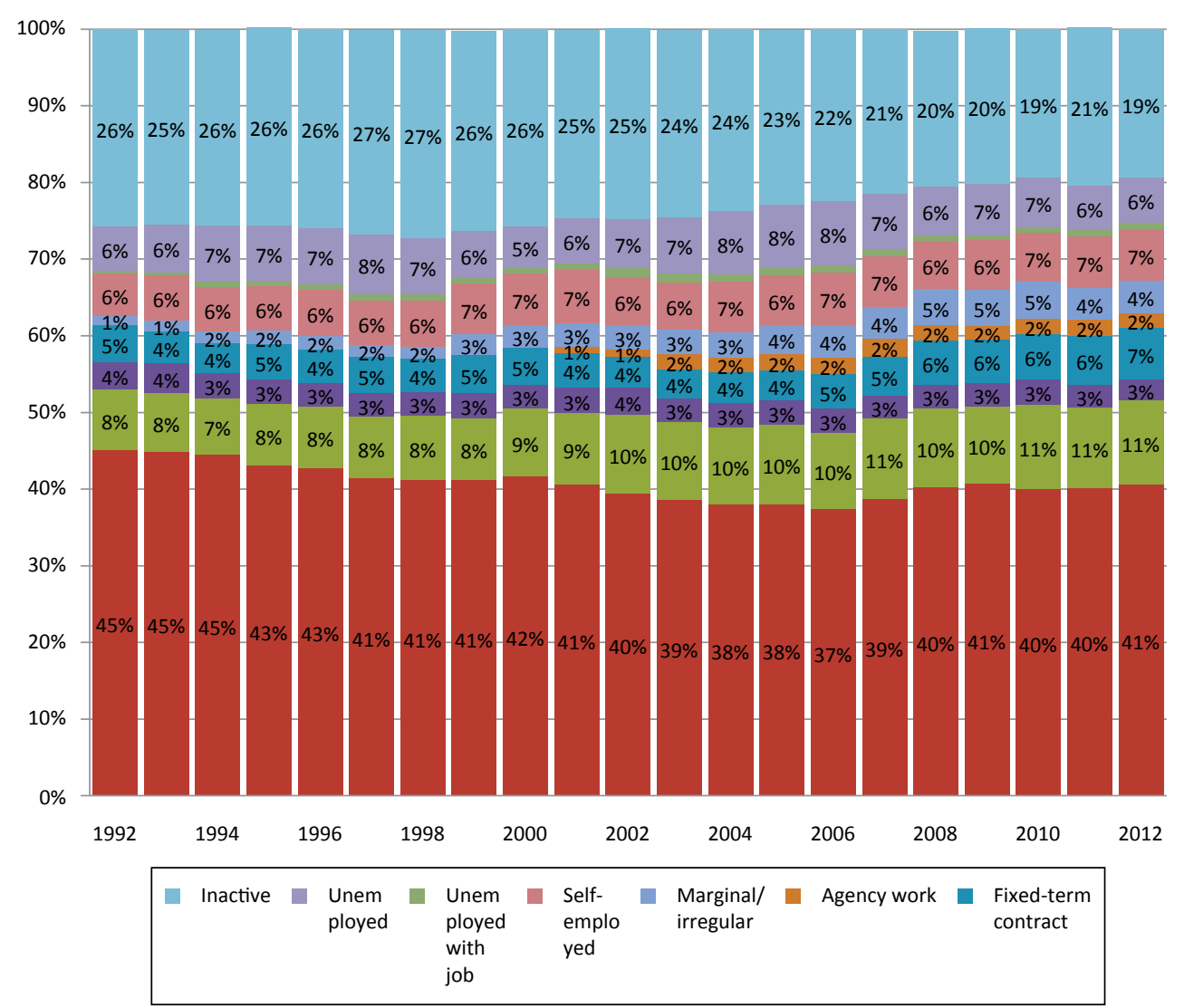


Table 2 Shares of different types of employment by sector in \%, 2010. (Source: Federal Statistical Office)

\begin{tabular}{|c|c|c|c|c|c|c|c|}
\hline & $\begin{array}{l}\text { Self-employed } \\
\text { without employees }\end{array}$ & $\begin{array}{l}\text { Self-employed } \\
\text { with employees }\end{array}$ & $\begin{array}{l}\text { Standard employ- } \\
\text { ment relationship }\end{array}$ & $\begin{array}{l}\text { Fixed-term } \\
\text { contract }\end{array}$ & $\begin{array}{l}\text { Part-time } \\
\text { employment }\end{array}$ & $\begin{array}{l}\text { Marginal } \\
\text { employment }\end{array}$ & $\begin{array}{l}\text { Temporary } \\
\text { agency work }\end{array}$ \\
\hline Private households & 5.8 & 0.5 & 12.5 & 4.8 & 65.4 & 51.0 & 0.0 \\
\hline Other economic activities & 6.9 & 4.5 & 42.6 & 14.1 & 21.6 & 14.7 & 10.6 \\
\hline Agriculture and forestry & 21.0 & 13.3 & 30.1 & 4.7 & 6.0 & 4.9 & 0.0 \\
\hline $\begin{array}{l}\text { Accommodation and food } \\
\text { service activities }\end{array}$ & 4.2 & 10.5 & 39.1 & 8.8 & 21.7 & 15.3 & 0.9 \\
\hline $\begin{array}{l}\text { Arts, entertainment and recre- } \\
\text { ation activities; other services }\end{array}$ & 17.7 & 5.7 & 38.9 & 9.0 & 17.4 & 10.8 & 0.8 \\
\hline $\begin{array}{l}\text { Professional, scientific and } \\
\text { technical activities }\end{array}$ & 16.8 & 10.6 & 45.3 & 4.9 & 10.3 & 3.8 & 0.6 \\
\hline $\begin{array}{l}\text { Human health and social } \\
\text { work activities }\end{array}$ & 3.6 & 4.5 & 53.7 & 10.1 & 18.5 & 7.6 & 0.6 \\
\hline $\begin{array}{l}\text { Wholesale and retail trade; } \\
\text { repair of motor vehicles }\end{array}$ & 5.0 & 5.7 & 54.3 & 6.2 & 17.6 & 9.6 & 1.1 \\
\hline Education & 4.9 & 0.8 & 56.6 & 12.9 & 15.0 & 4.5 & 0.5 \\
\hline $\begin{array}{l}\text { Information and communi- } \\
\text { cation activities }\end{array}$ & 10.7 & 3.3 & 59.2 & 5.2 & 8.7 & 4.9 & 0.8 \\
\hline Construction & 8.7 & 9.0 & 61.2 & 4.3 & 6.2 & 3.4 & 1.4 \\
\hline $\begin{array}{l}\text { Financial and insurance ac- } \\
\text { tivities; real estate activities }\end{array}$ & 7.7 & 4.9 & 64.5 & 3.0 & 11.3 & 3.3 & 1.3 \\
\hline Real estate activities & 2.0 & 2.2 & 49.2 & 4.9 & 7.2 & 3.9 & 1.2 \\
\hline Mining and quarrying & 1.4 & 2.2 & 75.6 & 4.9 & 5.6 & 3.1 & 3.2 \\
\hline $\begin{array}{l}\text { Energy, water, waste } \\
\text { management }\end{array}$ & 1.4 & 1.1 & 78.1 & 6.1 & 3.7 & 1.8 & 4.8 \\
\hline $\begin{array}{l}\text { Public administration, de- } \\
\text { fense, social security }\end{array}$ & 0.0 & 0.0 & 73.3 & 5.9 & 8.3 & 2.2 & 0.5 \\
\hline
\end{tabular}

These developments can hardly be understood without taking into account the sectoral and occupational changes that occurred over the last 10-15 years (see also Eichhorst et al. 2015). From Table 2 we can see the divergence in the shares of different forms of non-standard or atypical work across economic sectors. Some sectors rely heavily on marginal part-time work (private households, accommodation and food service, other services), fixed-term contracts (health and social services, but also education), freelance (arts and professional activities) or temporary agency work (classified as a separate sector here).

Furthermore, we can see from the scatter plot in Fig. 4 that in some service sector occupations job growth was achieved at the expense of a larger share of atypical workers in the respective occupation. This holds for customer service clerks (occupation 42 in ISCO-88), salespersons (52), personal and protective service workers (51), sales and service elementary occupations (91) and teaching associate professionals (33), i.e. low- to medium-skilled service workers with direct customer contact and public sector employees.

Addressing another dimension of segmentation, Table 3 shows the increase in pay dispersion among male and female full-time workers in Germany according to OECD data. The data show that Germany now has a sizeable low pay sector (below two thirds of the median gross hourly pay). Pay dispersion and low pay also grew more for women than for men. If we add in non-standard contracts, the low pay sector

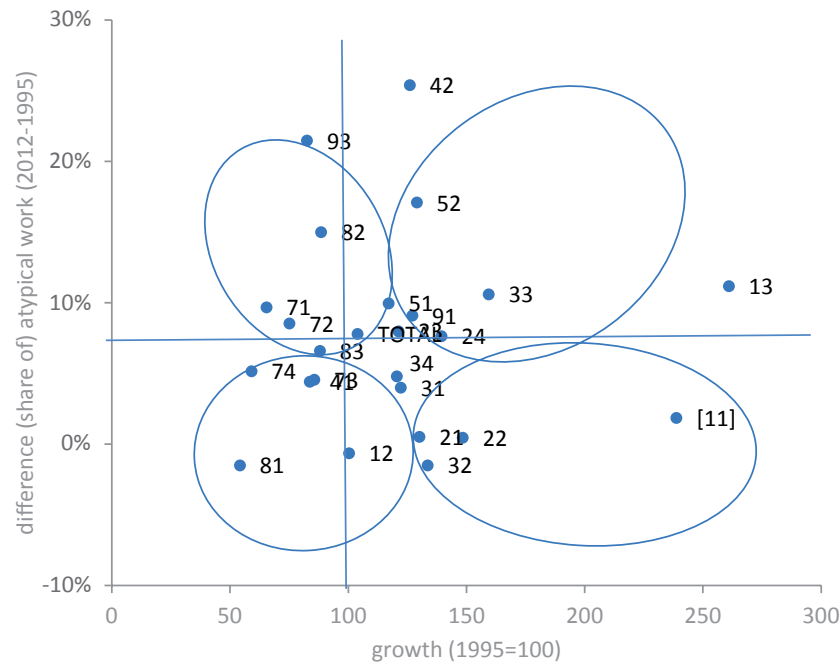

Fig. 4 Atypical work and employment growth by occupations (ISCO-88), 1995-2012. (Source: SOEP, weighted, dependent employment only, without agriculture (ISCO $88=61,92)$ and armed forces (ISCO88=01), own calculations. [] unreliable, insufficient number of cases $(<30$ cases $))$

is even bigger. Low pay is now a widespread phenomenon in Germany particularly affecting non-standard workers and certain medium and low-skilled occupations (see Table 4, Kalina and Weinkopf 2012). 
Table 3 Pay dispersion and low pay incidence in Germany. (Source: OECD Employment Statistics Database)

\begin{tabular}{|c|c|c|c|c|}
\hline & 2002 & 2005 & 2012 & Difference 2012-2002 \\
\hline \multicolumn{5}{|l|}{ All persons } \\
\hline Low pay incidence & 17.616 & 18.300 & 18.289 & 0.673 \\
\hline Decile 5/decile 1 & 1.769 & 1.869 & 1.769 & 0.000 \\
\hline Decile 9/decile 1 & 3.073 & 3.179 & 3.255 & 0.183 \\
\hline Decile $9 /$ decile 5 & 1.737 & 1.701 & 1.840 & 0.103 \\
\hline Women & & & 2011 & Difference 2011-2002 \\
\hline Low pay incidence & 28.500 & 30.700 & 26.930 & -1.570 \\
\hline Decile 5/decile 1 & 1.786 & 1.8333 & 1.87 & 0.084 \\
\hline Decile 9/decile 1 & 2.928 & 3.1597 & 3.164 & 0.236 \\
\hline Decile 9/decile 5 & 1.639 & 1.7235 & 1.692 & 0.053 \\
\hline Men & & & 2011 & Difference 2011-2002 \\
\hline Low pay incidence & 12.110 & 12.220 & 13.510 & 1.400 \\
\hline Decile 5/decile 1 & 1.688 & 1.6932 & 1.755 & 0.067 \\
\hline Decile 9/decile 1 & 3.019 & 2.8793 & 3.186 & 0.167 \\
\hline Decile $9 /$ decile 5 & 1.789 & 1.7005 & 1.816 & 0.027 \\
\hline
\end{tabular}

Table 4 Low pay by type of job, 2010. (Source: Federal Statistical Office)

\begin{tabular}{|c|c|c|c|c|c|c|c|}
\hline & \multirow[t]{2}{*}{ Total } & \multirow{2}{*}{$\begin{array}{l}\text { Standard } \\
\text { employment }\end{array}$} & \multicolumn{5}{|c|}{ Non-standard contracts } \\
\hline & & & $\begin{array}{l}\text { All non-stan- } \\
\text { dard contracts }\end{array}$ & $\begin{array}{l}\text { Part-time } \\
\text { work }\end{array}$ & $\begin{array}{l}\text { Fixed-term } \\
\text { contracts }\end{array}$ & $\begin{array}{l}\text { Marginal part- } \\
\text { time work }\end{array}$ & $\begin{array}{l}\text { Temporary } \\
\text { agency workers }\end{array}$ \\
\hline Total & 20.6 & 10.8 & 49.8 & 20.9 & 33.5 & 84.3 & 67.7 \\
\hline Women & 26.5 & 15.1 & 47.6 & 19.2 & 35.5 & 84.8 & 72.9 \\
\hline Men & 15.8 & 8.1 & 53.7 & 34.3 & 31.6 & 83.4 & 65.4 \\
\hline Less than upper secondary education & 52.8 & 22.7 & 77.8 & 44.7 & 62.2 & 88.1 & 85.5 \\
\hline Upper secondary education & 17.7 & 12.1 & 39.4 & 17.1 & 36.2 & 77.2 & 57.6 \\
\hline Tertiary education & 1.7 & 0.5 & 8.3 & 2.7 & 5.7 & 61.4 & 20.7 \\
\hline \multicolumn{8}{|l|}{ Selected occupational groups } \\
\hline Academic occupations & 3.0 & 1.0 & 10.5 & 3.5 & 5.7 & 64.9 & / \\
\hline $\begin{array}{l}\text { Technicians and equivalent non-tech. } \\
\text { occupations }\end{array}$ & 7.6 & 4.0 & 24.9 & 4.7 & 17.3 & 68.1 & 29.2 \\
\hline Office clerks & 23.4 & 10.9 & 48.1 & 13.2 & 39.4 & 80.3 & 62.5 \\
\hline Service and sales occupations & 42.3 & 28.4 & 65.4 & 30.0 & 58.3 & 88.6 & 72.1 \\
\hline Crafts & 16.1 & 11.1 & 48.7 & 32.6 & 31.3 & 81.0 & 47.6 \\
\hline Machine operators and assemblers & 23.7 & 17.1 & 60.6 & 33.2 & 39.7 & 89.3 & 63.0 \\
\hline Labourers & 61.5 & 39.7 & 79.2 & 56.3 & 70.7 & 90.3 & 89.2 \\
\hline
\end{tabular}

Finally, with respect to employment conditions, atypical work and low pay tend to go together in many occupations, as Fig. 5 shows. Again, the most affected are mainly those occupations where employment growth was associated with an increased share of atypical contracts $(42,51,52,91)$ and agency assigned work contracts (93).

Regarding mobility between different types of jobs, Fig. 6 shows year-to-year flows from non-standard contracts in the preceding year to the labour market status in the current year for 2008 up to 2011. These descriptive data show for example that during the period under scrutiny, about one third of all fixed-term contract workers moved to an open-ended contract (including vocational education or self-employment) in the subsequent year while $40-50 \%$ remained in a fixed-term contract. About $30 \%$ of all agency workers had left that status in the subsequent year in favour of a permanent full-time or part-time job, vocational train- ing or self-employed status. Persistence is quite high with marginal work, however, where about $50 \%$ of all marginal part-time workers remained in that category.

Taking a longer time perspective, as Fig. 7 shows, flows from fixed-term contracts to permanent jobs occur in about one third of all cases on a year-to-year basis with some notable cyclical variations. Over the last years, however, staying in a fixed-term employment status became somewhat more frequent.

We can further see in Table 5, covering the last 5 years (2007-2011), that about $71 \%$ of all working-age people in Germany did not experience non-standard work (fixedterm, marginal part-time or agency work), about $47 \%$ have always been in stable 'insider' jobs over a 5 -year period, and around $11 \%$ have not been in employment at all. Only a small group cumulates longer phases of non-standard work. 


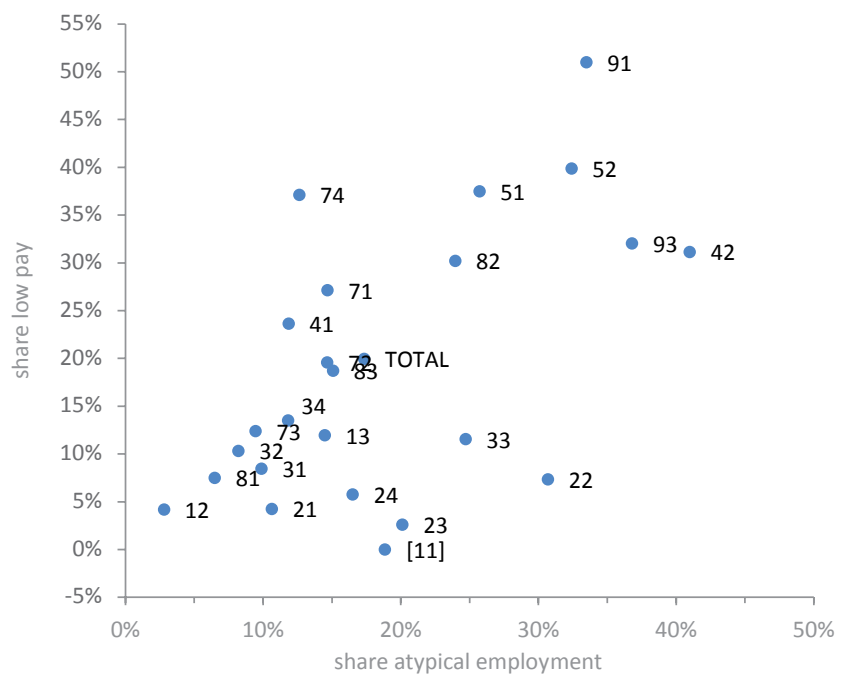

Fig. 5 Atypical work and low pay by occupations. (Source: SOEP, weighted, dependent employment only, without agriculture (ISCO $88=61.92)$ and armed forces (ISCO88 $=01)$, own calculations. [] unreliable, insufficient number of cases ( $<30$ cases $)$ )
Going beyond descriptive evidence, a large body of recent research has analysed both wage gaps and transition probabilities between atypical and standard employment types. Regarding wage gaps experienced by fixed-term workers, a recent study shows that, controlling for personal characteristics and occupational and firm-specific effects, there is a wage gap of about $10 \%$ attributable to the type of contract (Pfeifer 2012). With respect to temporary work agency employees, controlling for individual characteristics, there is a considerable raw wage gap stemming from differences in the collective agreements of agency firms and user firms, tasks, skills and experience amounting to about 40-50\% (Baumgarten et al. 2012). Controlling for socioeconomic characteristics of workers and job characteristics, the corrected wage gap has been estimated at around $32 \%$ in the past (Jahn 2010); but taking into account tenure and work experience it was estimated at around $15-22 \%$ for full-time agency workers (Lehmer and Ziegler 2011). Part-time work is also characterized by a wage gap after correcting for worker and job characteristics (Wolf 2010).
Fig. 6 Flows from non-standard work in the previous to current year

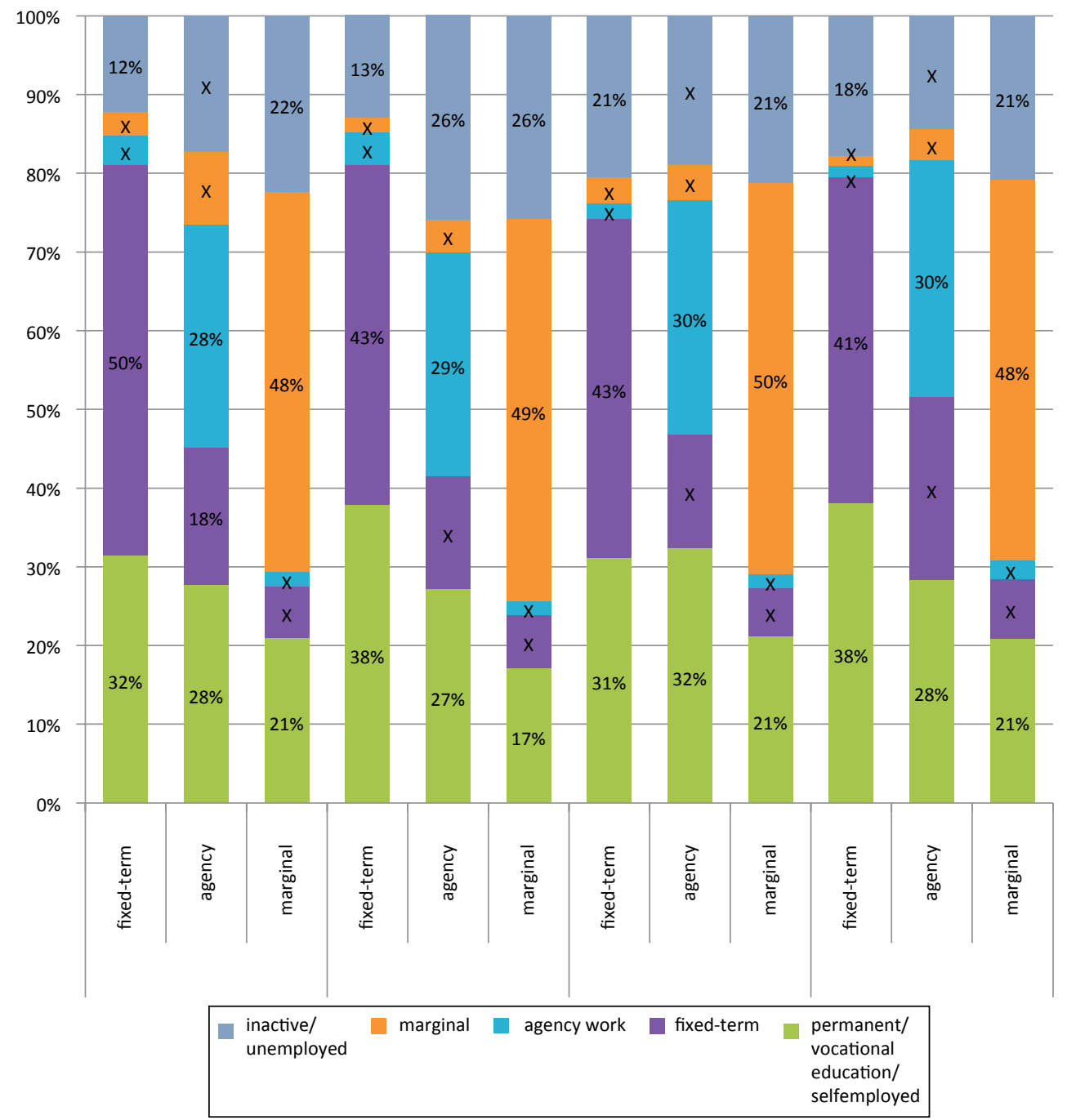


Fig. 7 Flows from fixed-term contracts in previous to current year

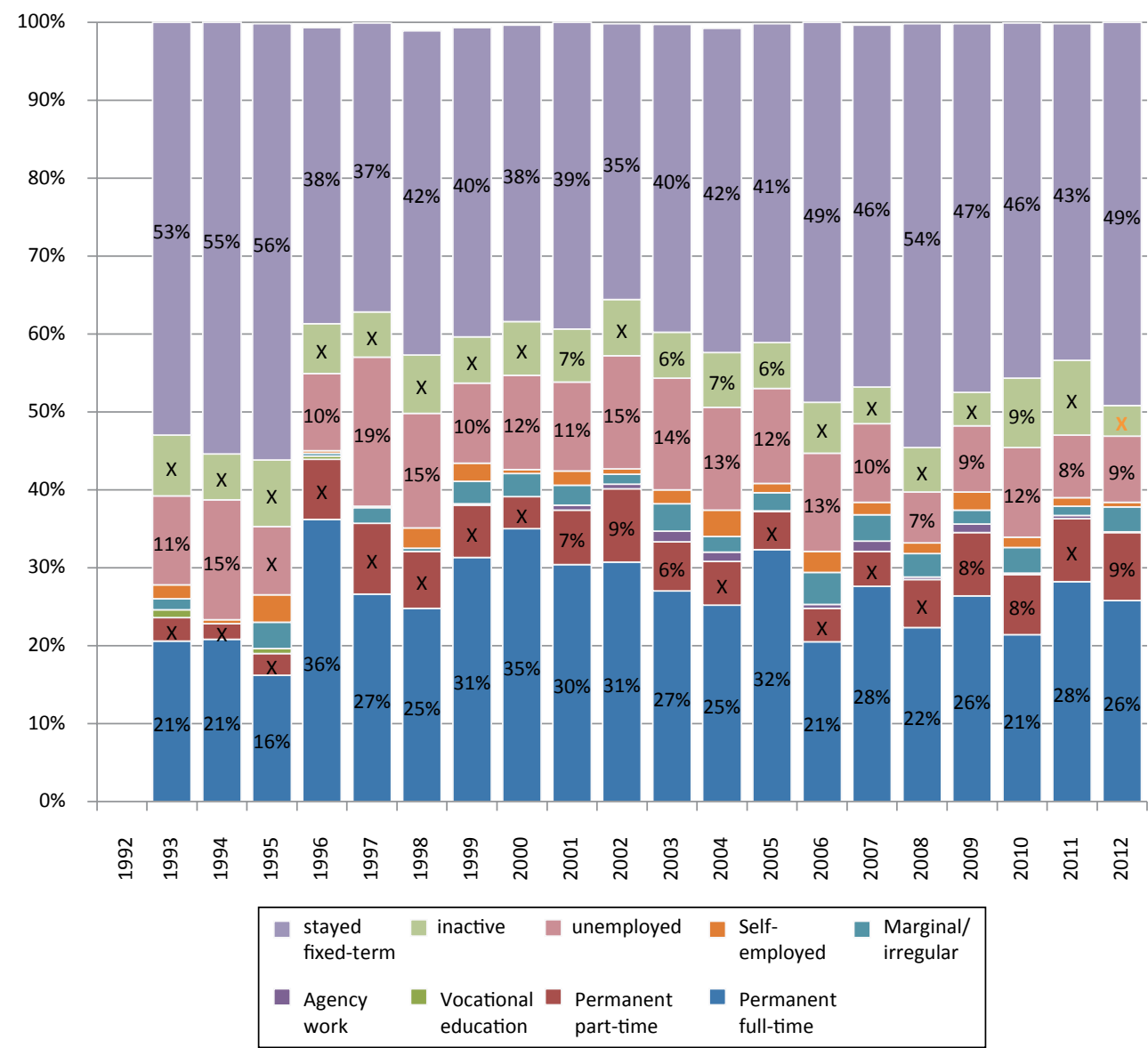

Table 5 Frequency of atypical employment between 2007 and 2011. (Source: SOEP, own calculations)

\begin{tabular}{lc}
\hline How often in atypical employment—on a yearly basis (in percent) \\
\hline (0) never & $\mathbf{7 0 . 9 3 \%}$ \\
Never, always inside employment & $47.20 \%$ \\
Never, always outside employment & $10.80 \%$ \\
Never, switching between employment and & $12.93 \%$ \\
unemployment/inactivity & \\
(1) only once & $\mathbf{1 2 . 4 2 \%}$ \\
(2) & $\mathbf{7 . 2 0 \%}$ \\
(3) & $\mathbf{3 . 9 5 \%}$ \\
(4) & $\mathbf{3 . 7 0 \%}$ \\
(5) always & $\mathbf{1 . 8 0 \%}$ \\
\hline
\end{tabular}

Furthermore, there is some evidence that marginal part-time workers receive significantly lower gross hourly wages than other part-time workers (Voss and Weinkopf 2012).

Research now shows that transitions from a fixed-term to a permanent contract is relatively frequent in Germany, in particular for young people entering the private sector for whom fixed-term contracts (outside genuine apprenticeships which make up for about half of all fixed-term contracts) can be seen as an extended probationary period, while continuous renewals of fixed-term contracts are even more widespread in the public, academic and social sector where specific conditions prevail (Bellmann et al. 2009; Hohendanner 2010; Boockmann and Hagen 2005; Lehmer and Ziegler 2010). Mobility from temporary agency work to permanent (direct) employment is more problematic, however, given the distinct institutional arrangement and functional logic of agency work in Germany (Baumgarten et al. 2012; Spermann 2011; Kvasnicka 2008; Holst et al. 2009; Lehmer and Ziegler 2010; Crimmann et al. 2009). With respect to part-time work, we see significant employment stability of (voluntary) part-time work in Germany, which can also be perceived as a standard employment contract at reduced weekly hours. Yet most part-time workers likely prefer to expand their working time (Holst and Seifert 2012). Mobility barriers that exist with respect to marginal part-time work can be attributed to the prohibitive marginal tax rates experienced at the threshold earnings level in this segment (Eichhorst et al. 2012; Freier and Steiner 2008). Mobility from low pay to higher wages is more frequent with younger and better skilled workers as well as male workers in general, in particular if they can leave (i) firms with large segments of low paid jobs and (ii) unskilled service occupations (Mosthaf et al. 2011). 


\section{Explaining the structural change}

When trying to explain the pattern of labour market duality discussed above, we can argue that besides structural change and strategic behaviour of market actors, in particular employers, labour market institutions and reforms play a major role in shaping the functioning of the German labour market, specifically regarding atypical work. While there is major stability around the institutional provisions governing standard employment contracts, there have been major structural changes mainly affecting non-standard or 'atypical' jobs. It is true that there has always been a certain segmentation of the industrial labour force in Germany based on skill requirements and mirrored by patterns of pay and tenure, but institutional flexibility has grown over time, which major implications for the spread and character of atypical work.

Regarding open-ended full-time contracts, dismissal protection has remained more or less at the same level as it used to be in the 1990s. Reforms marginally liberalising dismissal protection by lifting the company size threshold and narrowing the social selection criteria for fair dismissals introduced in the mid-1990s were undone in the late 1990s and partially restored in the early 2000s. Apart from that no major changes were implemented on the legislative side. Social protection of fully socially insured permanent employees has changed, however, in particular by shortening the maximum duration of unemployment insurance benefit receipt for older workers, a cut from 32 to 18 month and later extended to 24 months again.

More important for the development of standard contracts was the restructuring of collective bargaining and companylevel strategies. First, beginning in the 1990s, sectoral negotiations linking wages, working time and job stability were mostly characteristic of the core manufacturing sector in Germany. This led to increased flexibility within collective agreements regarding pay and working time adjustment. In the medium and long run, these steps of restructuring contributed to regaining competitiveness in the export-oriented sector and the relative stabilization of standard employment contracts for the core labour force, albeit at conditions which are less 'rigid' and more flexible than in the past. At the same time, however, manufacturing employers also promoted outsourcing and offshoring, thereby redrawing the borders of the core workforce more narrowly. One has to note further that major employment gains in standard employment contracts occurred in the private service sector, most notably in highly skilled occupations, which offset the stagnating and rather shrinking employment capacity of the manufacturing sector. However, collective bargaining coverage is much lower in many of the most dynamic private services, which also contributes to the increase in wage dispersion and low pay (Dustmann et al. 2009; Dustmann et al. 2014).
With respect to non-standard contracts, a number of changes have shown medium and long run consequences of some deregulation at the margin of the labour market. These changes were more significant than legislative modifications of the standard employment contract, i.e. dismissal protection. First, over the last 3 decades, starting in the mid-1980s, fixed-term contracts have been liberalised in a step-wise manner with only a few smaller steps reversing parts of the deregulatory path. Currently, fixed-term contracts without having to provide a valid reason are legal in Germany for up to 2 years with the possibility of up to three renewals. However, since $2000 / 01$ it is no longer possible to have a fixed-term contract with the same employer if fixed-term employment had already taken place in the past. Furthermore, since the mid-2000s fixed-term employment without having to provide a valid reason is basically unrestricted when hiring older unemployed individuals and during the first years of a business start-up. Fixed-term contracts are also feasible in cases of a valid reason, of course. In the public sector project-related funding is often taken as a reason to employ workers only on a temporary basis; and in the academic sector, specific legal provisions allow for extended periods of fixed-term employment up to 12 years. One has to note, however, that dismissal protection for permanent staff is even stricter in the public sector than in the private one. It is extremely difficult to fire civil servants and public employees with certain tenure. This also explains the reluctance of public employers to convert temporary into permanent jobs.

As with fixed-term employment, temporary agency work has also been increasingly liberalised over the last decades, with the most important deregulatory step being taken in 2003 in the context of the Hartz reforms. Here, virtually all restrictions regarding agency work, such as the maximum duration of assignments, the ban on synchronicity between employment contract and individual assignments or the ban on rehiring, were lifted. At the same time, equal pay and equal treatment were stipulated as a general principle. However, deviations were allowed for initial periods of employment after phases of unemployment and, most importantly, by way of collective agreements. This led to virtually full coverage of the agency sector by collective agreementshowever, the wages set are now significantly below those of major user sectors such as the metal working sector. Therefore, while the original intention of promoting temporary work agencies was to strengthen the placement capacities for the unemployed, contradictions, largely due to differing wage scales and assignments that can be made for an indeterminate period of time, in labour market reforms in Germany actually led to the creation of a peculiar wage gap between direct employees in manufacturing and temporary agency workers performing similar tasks. 
Most important, but outside employment protection legislation, was the change in the regulation of so-called marginal part-time work in 2003, as part of the Hartz reform package. In contrast to earlier, more restrictive regulation of small part-time jobs, the 2003 reform lifted the earnings threshold to 400 EUR per month (450 EUR as of 2013), abolished the weekly working hours ceiling of $15 \mathrm{~h}$ and allowed for marginal part-time work as a second job. What is peculiar about marginal part-time work or Minijobs in Germany is the fact that employment in marginal part-time is not liable for income taxes and employee social insurance contributions while at the same time not providing full social protection. Hence, earnings from Minijobs can be received without a reduction of taxes and social insurance contributions. But when earning more than 450 EUR (or if combining more than one of these jobs), full taxation and a gradual phase-in into social insurance begin. Therefore, the 450 EUR threshold acts as a strong disincentive to earn or work more. This arrangement, however, is quite attractive and popular with secondary earners such as married women, people with a fully socially protected first job as well as students and pensioners. Not only the expansion of Minijobs has occurred since 2003 but also the further restructuring of some private services, such as retail trade or hotels and restaurants, where most of these jobs are concentrated. There is some evidence that regular part-time and full-time jobs have been crowded out, and employers have reaped part of the benefits on the employee side by reducing gross hourly wages (Eichhorst et al. 2012; Hohendanner and Stegmaier 2012).

In-work benefits also contribute to the more widespread appearance of low pay jobs since the Hartz IV reform simplified access to social assistance as a means to top up low earnings due to earnings disregard clauses. This can induce employers to lower gross wages if there is no binding wage floor. Hartz IV, one has to note, was one of the core pillars of activation policies in Germany (Eichhorst et al. 2008; Ebbinghaus and Eichhorst 2009). It radically changed the German system of wage-related welfare. The new scheme was designed to prevent poverty while at the same time lowering (long-term) unemployment. The major lever to achieve this goal was the shortening of individual unemployment spells through accelerated job placement and more coherent activation of the beneficiaries of unemployment insurance benefits and unemployed on means-tested assistance (Clasen and Goerne 2011). Less generous benefits for the long-term unemployed, stricter job suitability criteria and more effective job placement and active labour market schemes were the instruments to achieve this goal. Benefit recipients can be demanded to take up any job and follow obligations stemming from integration agreements. The practical enforcement of "rights and duties", however, is the core element of the Hartz reforms. This activation strat- egy is implemented in virtually every element of the labour market policy framework. All major steps of deregulation of non-standard work, such as agency work, self-employment support and marginal part-time work, were intended to lower barriers for job creation, specifically in the service sector, and ease access to flexible jobs as stepping stones for unemployed or inactive persons, in particular for those with limited skills or work experience.

Hence, one can argue that the Hartz reform package established a rather 'implicit' linkage between (i) activation-oriented active labour market and social policies aimed at reducing benefit dependency and increasing labour supply and (ii) labour market flexibilisation aiming at more dynamic job creation, in particular in the service sector (Eichhorst et al. 2008; Ebbinghaus and Eichhorst 2009; Caliendo and Hogenacker 2012). The increase in labour supply (due to activation) was to be absorbed by a more flexible labour market, i.e. in "new" flexible segments such as start-ups, part-time and minor jobs, but also temporary agency work. The expectations that of the Hartz reforms, such as significantly reducing unemployment in Germany and overcoming persistently high structural unemployment, have partly been realised as the increase in total employment and the related decline in inactivity and unemployment show. Yet, employers could now shift more and more employment risks onto the flexible part of the labour force and assign more tasks to flexible and low paid workers. The widespread perception is that the German labour market has become more flexible and more conducive to the creation of jobs, but on average this has come at the price of having more heterogeneity between jobs and an increasingly large share of non-standard, i.e. more fragile, employment and low pay. The growth of the secondary segment has also contributed to fears in the core segment regarding downward mobility of pay and employment stability.

\section{Concluding remarks}

Our paper makes two contributions, one empirical and one theoretical. The empirical contribution concerns our characterization of the effects of recent labour market policy reforms. In contrast to the more pessimistic characterizations of labour market liberalization (see, for example, Streeck 2009) we highlight some of the positive dimensions of recent changes, especially the role of non-standard work as a bridge to standard work, and the increase in overall employment, in particular in services, so that we can see dualisation also as part of a more or less successful adaptation (see for example, Reisenbichler and Morgan 2012; Rinne and Zimmermann 2011; Hassel 2014). The paper's theoretical contribution is its focus on the permeability of the labour market segments. We argue that the dividing line 
between standard and non-standard work is not as clear and permanent as, for example, Palier and Thelen (2010) claim.

All in all, it is fair to say that the German labour market underwent a major transformation over the last 10-15 years. New jobs in service occupations have contributed to a significantly higher level of employment compared to earlier phases, and many of these jobs are in non-standard forms of contracts. A major dividing line lies between regular, permanent part-time and marginal part-time jobs. The secondary segments of the labour market are clearly characterized by sectoral and demographic patterns. This pattern of employment duality seems to become more important over time as the labour market expands, sectoral shifts occur, employers' room to manoeuver increases, and working conditions also react to industrial relations/organization and labour demand/supply patterns. A parallel development can also be shown with pay inequalities. Clearly, the low pay sector has grown in Germany as has the overall pay dispersion. While it is true that non-standard contracts in general have a higher share of low pay earners than standard employment, the variation of pay amongst employees on full-time openended contracts has increased as well. Here, the coverage by collective agreements makes a major difference.

The implications are somewhat ambiguous though. One has to note that the core of the labour market in Germany is still characterized by employment stability and decent wages, in particular in skill-intensive service and manufacturing sectors covered by collective agreements and social protection. This backbone of the German economic model has proven to be both adaptable and competitive in a globalized economy. Furthermore, one has to note that stability and flexibility of employment are shared unequally across sectors, occupations and socio-economic groups. Still, it is true that the secondary segment of non-standard jobs faces major employment risks and acts as an additional buffer that eases the adjustment pressure on the core. Yet, non-standard jobs contribute to better labour market access and additional job creation, which generates additional income from work.

As a general assessment of labour market segmentation in Germany, one can argue that the variety of employment types and pay dispersion increased significantly since the turn of the century, in particular in response to institutional reforms implemented after 2003. Most of the non-standard jobs, however, can be seen as additional employment opportunities created by institutional liberalisation at the margin of the labour market and the corresponding adaptive behaviours of market actors. Labour market duality has grown in importance over time, moving Germany away from a situation of few, but quite equal jobs to a constellation characterized by more, but also increasingly unequal jobs. However, job quality in terms of pay, employment stability, job security has not declined in general, and some forms of nonstandard work provide effective entry points and stepping stones in the German setting. Legislative changes are not the only factor, however. Many other factors such as sectoral change, the further development and relative shrinkage of the scope of collective bargaining and company-level practices all have to be taken into account. Despite some areas where we could observe some crowding-out of standard contracts by atypical forms of employment, the growth in the non-standard part of the German labour market can be seen as complementary.

The issue of labour market dualisation has risen in public and political attention in recent years, with a major campaign of the trade unions pushing for minimum wage levels and some re-regulation of the labour market. The major issue here is to reduce the regulatory gap between standard and non-standard types of jobs without making the German labour market overly rigid again, thus paving the way to a smoother transition between jobs and realizing the full potential of flexible jobs as stepping stones to permanent positions (or from low pay to medium pay).

Regarding fixed-term contracts (mainly in the public sector), softening employment protection for permanent staff in public sector jobs to the level of dismissal protection seen in the private sector in exchange for easier access to openended contracts in this sector could be one solution. A general revision of dismissal protection for permanent workers in exchange for a legal entitlement to severance pay proportional to salaries and tenure combined with some limitations on fixed-term contracts could help ease segmentation along this line. Yet, as many examples from other European countries show, all reforms questioning dismissal protection are difficult in politico-economic terms; therefore, they do not rank high on the policy agenda. In fact, German employers have adjusted to the availability of different types of contracts, and trade unions (and works councils) implicitly also accept the segmentation of the labour force rather than challenge the employment protection of permanent staff.

The situation is less deadlocked in the area of temporary agency work. Widespread uneasiness with the current working conditions of agency workers has fuelled a debate about introducing 'real' equal pay and equal treatment through legislative changes. Trade unions in particular have pushed for this. What we can observe most recently is successful collective bargaining in the metal working and other sectors to move towards stronger co-determination regarding the use of agency work and stronger equal pay in practice. From a trade union perspective, though, this issue can only be addressed via collective agreements in areas where they are strong enough and where employers are willing to compromise on this as part of a larger bargaining deal. Furthermore, the coalition formed by Christian Democrats and Social Democrats in 2013 has agreed to re-regulate temporary agency work by introducing equal treatment after 9 months of assignment as well as limit the maximum dura- 
tion of assignments to 18 months. This is currently still a pending issue though.

Marginal part-time could be reformed in order to promote more substantial part-time work-this would imply, however, removing the tax privilege of Minijobs and joint income taxation of married couples (Eichhorst et al. 2012) which tend to benefit middle-class household work arrangements. Hence, reforms in these are unpopular as they affect core constituencies of major political parties and the trade unions.

Regarding wage dispersion, the weakness of collective bargaining in the private service sector, in particular in medium- and low-skill occupations, has raised attention of the issue of setting binding minimum wages since the mid-2000s. This was virtually a non-issue for many years as trade unions (and employers) always saw wage bargaining as their genuine responsibility, but faced with increasing low pay and limited capacities to establish collective agreements, the trade unions started to push for a general statutory minimum wage, a political project that is also popular with the majority of German voters. Over the last years and in different government constellations, however, collectively agreed minimum wages in an increasing number of sectors have been made generally binding via existing legislation on the posting of workers or, in the case of agency workers, on the regulation of temporary work agencies. The new statutory minimum wage of 8.50 EUR per hour effective as of January 2015 - with a transition period of 2 years for existing and binding collectively agreed minimum wageshas established a binding minimum wage floor for virtually all categories of workers (except for young people and apprentices) and all sectors for the first time in Germany. Along with the expected interventions into agency work, the relatively high statutory minimum wage is the most important reform breaking with the deregulatory approach adopted about 10 years ago. While designed to limit the dispersion of wages and working conditions, the re-regulatory approach may also trigger new forms of circumvention, such as a resort to undocumented overtime or more bogus self-employment.

Apart from the current regulatory stance of German politics, in the medium perspective we can certainly expect further creative adjustment of social partners and collective bargaining as well as company-level practices to promote and safeguard employment of permanent skilled staff. This is particularly true in a situation where skilled labour becomes a scarce resource due to demographic ageing but continues to be essential for the German production model. Social partners continue to be of major importance in the well-established core sectors of the German economy. This gives a strong role to employers and employees to negotiate according to their individual market position. But for the increasingly large margin of the labour market though, government action is certainly crucial. Where the social partners are unable or unwilling to act and intervene, the state, i.e. through political decisions, will become more important. This holds for institutional arrangements governing non-standard forms of employment and for questions regarding the establishment of minimum pay provisions.

\section{Kurzfassung}

Unsere Studie leistet zwei Beiträge, einen empirischen und einen theoretischen. Der empirische Beitrag betrifft unsere Einschätzung über die Auswirkungen der jüngsten Arbeitsmarktreformen. Im Gegensatz zu der eher pessimistischen Einschätzung der Arbeitsmarktliberalisierung (vgl. z. B. Streeck 2009) heben wir die positiven Effekte der jüngsten Veränderungen, vor allem die Rolle von atypischer Beschäftigung als eine mögliche Brücke in ein Normalarbeitsverhältnis und den Anstieg in der Gesamtbeschäftigung, insbesondere im Dienstleistungssektor, hervor, so dass wir die Dualisierung als Teil von einer mehr oder weniger erfolgreichen Anpassung sehen (vgl. zum Beispiel, Reisenbichler und Morgan 2012; Rinne und Zimmermann 2011; Hassel 2014). Der theoretische Beitrag liegt in dem Fokus auf die Durchlässigkeit der Arbeitsmarktsegmente. Wir behaupten, dass die Trennlinie zwischen normaler und atypischer Beschäftigung nicht so eindeutig und dauerhaft ist, wie es zum Beispiel Palier und Thelen (2010) behaupten.

Generell kann man sagen, dass der deutsche Arbeitsmarkt in den letzten 10 bis 15 Jahren einen großen Wandel vollzogen hat. Neue Arbeitsplätze in Dienstleistungsberufen führen, im Vergleich zu früheren Phasen, zu einem deutlich höheren Beschäftigungsniveau, wobei viele dieser Arbeitsplätze atypisch sind. Es verläuft beispielsweise eine klare Grenze zwischen dauerhaften Teilzeitjobs und geringfügiger Beschäftigung. Der sekundäre Arbeitsmarkt ist durch branchenspezifische und demographische Muster gekennzeichnet. Diese Struktur der Arbeitsmarktdualisierung ist über die Zeit deutlicher geworden und scheint an Bedeutung zu gewinnen, da der Arbeitsmarkt wächst, die Branchen sich verschieben, der Handlungsspielraum der Arbeitgeber sich vergrößert und sich die Arbeitsbedingungen an die veränderten Strukturen der industriellen Beziehungen und Strukturen von Arbeitsnachfrage und -angebot anpassen. Eine parallele Entwicklung kann auch hinsichtlich der Ungleichheit der Bezahlung gezeigt werden. Es ist offensichtlich, dass der Niedriglohnsektor ebenso wie das Lohngefälle in Deutschland gewachsen ist. Zwar ist der Anteil von Geringverdienern bei atypischen Arbeitsverhältnissen größer als bei Normalarbeitsverhältnissen, jedoch hat die Lohnvarianz ebenso unter Arbeitsnehmern mit unbefristeten Normalarbeitsverhältnissen zugenommen. Hierbei spielt die Abdeckung durch Tarifabkommen eine bedeutende Rolle. 
Die Auswirkungen dieser Entwicklungen auf das deutsche Beschäftigungssystem sind durchaus ambivalent. Es ist zu berücksichtigen, dass der Kern des deutschen Arbeitsmarktes immer noch von Beschäftigungsstabilität und angemessenen Löhnen geprägt ist, dies gilt besonders für wissensintensive Dienstleistungs- und Fertigungsbranchen, die durch Tarifverträge und soziale Absicherung abgedeckt sind. Das Rückgrat des deutschen Wirtschaftsmodells hat sich in einer globalisierten Wirtschaft als anpassungsfähig und wettbewerbsfähig erwiesen. Darüber hinaus ist festzustellen, dass die Beschäftigungsstabilität und -flexibilität über Branchen, Berufe und sozioökonomischen Gruppen hinweg ungleich verteilt ist. Allerdings ist es Tatsache, dass das sekundäre Segment atypischer Beschäftigung große Beschäftigungsunsicherheiten mit sich bringt und als zusätzlicher Puffer wirkt, der den Anpassungsdruck auf den Kern des Arbeitsmarktes vermindert. Dennoch trägt atypische Beschäftigung dazu bei, den Zugang zum Arbeitsmarkt zu verbessern und zusätzliche Arbeitsplätze zu schaffen, was zusätzliches Arbeitseinkommen generiert.

Für die Gesamtbeurteilung der Segmentierung des deutschen Arbeitsmarktes lässt sich sagen, dass die Vielfalt der Beschäftigungsformen und die Variation in der Bezahlung seit 2000, insbesondere in Folge der institutionellen Reformen, die nach 2003 eingeführt wurden, erheblich angestiegen ist. Die meisten atypischen Arbeitsplätze können als zusätzliche Beschäftigungsmöglichkeiten betrachtet werden, die durch institutionelle Liberalisierung am Rande des Arbeitsmarktes und durch das entsprechende adaptive Verhalten der Marktakteure, geschaffen worden ist. Die Dualisierung des Arbeitsmarktes hat an Bedeutung gewonnen, Deutschland bewegt sich weg von einer Situation mit wenigen, aber ziemlich gleichen Arbeitsplätzen, hinzu einer Konstellation mit mehr, aber zunehmend ungleichen Arbeitsplätzen. Jedoch hat die Arbeitsqualität hinsichtlich Bezahlung, Beschäftigungssicherheit und Arbeitsplatzsicherheit insgesamt nicht abgenommen, und einige Arten atypischer Beschäftigung bieten einen effektiven Einstieg und ein Sprungbrett in den deutschen Arbeitsmarkt. Hierbei sind Gesetzesänderungen jedoch nicht die einzige treibende Kraft. Viele andere Aspekte, wie der Strukturwandel, der Fortschritt und der relative Rückgang des Geltungsbereiches von Tarifverhandlungen und Unternehmenspraktiken, müssen berücksichtigt werden. Trotz einiger Bereiche, in denen wir eine gewisse Verdrängung von Normalarbeitsverträgen durch atypische Arbeitsverträge beobachten können, kann das Wachstum des Anteils an atypischer Beschäftigung als komplementär betrachtet werden.

Die öffentliche und politische Aufmerksamkeit für die Dualisierung des Arbeitsmarktes ist in den letzten Jahren, nicht zuletzt durch eine große Kampagne der Gewerkschaften, die Mindestlöhne und einige Re-Regulierung des Arbeitsmarktes fordert, gewachsen. Aus arbeitsmarktpoli- tischer Sicht liegt die Herausforderung darin, den Abstand in der Regulierungsintensität zwischen Normalarbeitsverträgen und atypischen Arbeitsverträgen zu verringern ohne den deutschen Arbeitsmarkt wieder zu starr zu machen, um den Übergang zwischen Arbeitsplätzen zu vereinfachen und das volle Potential von flexiblen Arbeitsplätzen als Sprungbrett in unbefristete Verträge bzw. von Niedriglöhnen zu mittleren Löhnen auszuschöpfen.

\section{References}

Baumgarten, D., Kvasnicka, M., Landmann, J., Thode, E.: Herausforderung Zeitarbeit. Studie im Auftrag der Bertelsmann Stiftung, Gütersloh (2012)

Bellmann, L., Fischer, G., Hohendanner, C.: Dynamik und Flexibilität auf dem deutschen Arbeitsmarkt. Handbuch Arbeitsmarkt. 359-401 (2009)

Boeri, T.: Institutional reforms and dualism in European labor markets, Chap. 13. In: Ashenfelter, O., Card, D. (eds.) Handbook of Labor Economics, vol. 4B, pp. 1173-1236. Elsevier, Amsterdam (2010)

Boockmann, B., Hagen, T.: Befristete und andere 'atypische' Beschäftigungsverhältnisse: Wird der Arbeitsmarkt funktionsfähiger? Z. Arbeitsmarktforschung. 38(2-3), 305-324 (2005)

Caliendo, M., Hogenacker, J.: The German labor market after the great recession: Successful reforms and future challenges. IZA J. Eur. Labor. Stud. 1(1), 1-24 (2012)

Clasen, J., Goerne, A.: Exit Bismarck, enter dualism? Assessing contemporary German labour market policy. J. Soc. Policy. 40(4), 795-810 (2011)

Crimmann, A., Ziegler, K., Ellguth, P., Kohaut, S., Lehmer, F.: Forschungsbericht zum Thema Arbeitnehmerüberlassung Endbericht zum 29. Mai 2009. IAB, Forschungsbericht Arbeitsmarkt 397, Nürnberg (2009)

Doeringer, P.B., Piore, M.J.: Internal Labor Markets and Manpower Analysis. Heath Lexington Books, Lexington (1971)

Dustmann, C., Ludsteck, J., Schönberg, U.: Revisting the German wage structure. Quart. J. Econ. 124(2), 843-888 (2009)

Dustmann, C., Fitzenberger, B., Schönberg, U., Spitz-Oener, A.: From sick man of Europe to economic superstar: Germany's resurgent economy. J. Econ. Perspect. 28(1), 167-188 (2014)

Ebbinghaus, B., Eichhorst, W.: Employment regulation and labor market policy in Germany, 1991-2005. In: de Beer, P., Schils, T. (eds.) The Labour Market Triangle Employment Protection, Unemployment Compensation and Activation in Europe, pp. 119-144. Edward Elgar, Cheltenham (2009)

Eichhorst, W.: The unexpected appearance of a new German model. Brit. J. Ind. Relat. 53(1), 49-69 (2015)

Eichhorst, W., Marx, P.: Reforming German labor market institutions: A dual path to flexibility. J. Eur. Soc. Policy. 21(1), $73-87$ (2011)

Eichhorst, W., Grienberger-Zingerle, M., Konle-Seidl, R.: Activation policies in Germany: from status protection to basic income support. In: Eichhorst, W., Kaufmann, O., Konle- Seidl, R. (eds.) Bringing the Jobless into Work?, pp. 17-67. Springer, Berlin (2008)

Eichhorst, W., Hinz, T., Marx, P., Peichl, A., Pestel, N., Siegloch, S., Thode, E., Tobsch, V.: Geringfügige Beschäftigung: Situation und Gestaltlungsoptionen. IZA Research Report 47, Bonn (2012)

Eichhorst, W., Marx, P., Tobsch, V.: Non-standard employment across occupations in Germany: The role of replaceability and labour market flexibility. In: Eichhorst, W., Marx, P. (eds.) Non-Standard Employment in a Comparative Perspective, pp. 29-51. Edward Elgar, Cheltenham (2015) 
Emmenegger, P., Häusermann, S., Palier, B., Seeleib-Kaiser, M. (eds.): The Age of Dualization: The Changing Face of Inequality in Deindustrializing Societies. Oxford University Press, Oxford (2012)

Freier, R., Steiner, V.: 'Marginal employment': stepping stone or dead end? Evaluating the German experience. Z. Arbeitsmarktforschung. 41(2-3), 223-243 (2008)

Goos, M., Manning, A., Salomons, A.: Explaining job polarization: Routine-biased technological change and offshoring. Amer. Econ. Rev. 104(8), 2509-2526 (2014)

Hassel, A.: The paradox of liberalization. Understanding dualism and the recovery of the German political economy. Brit. J. Ind. Relat. 52(1), 57-81 (2014)

Hohendanner, C.: Unsichere Zeiten, unsichere Verträge? Befristete Arbeitsverträge zwischen Auf- und Abschwung. IAB Kurzbericht 14 (2010)

Hohendanner, C., Stegmaier, J.: Geringfügige Beschäftigung in deutschen Betrieben: Umstrittene Minijobs. IAB Kurzbericht 24 (2012)

Holst, E., Seifert, H.: Arbeitszeitpolitische Kontroversen im Spiegel der Arbeitszeitwünsche. WSI Mitteilungen. 65(2), 141-149 (2012)

Holst, H., Nachtwey, O., Dörre, K.: Funktionswandel von Leiharbeit. Neue Nutzungsstrategien und ihre arbeits- und mitbestimmungspolitischen Folgen'. Studie im Auftrag der Otto Brenner Stiftung. Otto Brenner Stiftung, Frankfurt (2009)

Jahn, E.: Reassessing the wage penalty for temps in Germany. J. Econ. Stat. 230, 208-233 (2010)

Kalina, T., Weinkopf, C.: Niedriglohnbeschäftigung 2010: Fast jede/r Vierte arbeitet für Niedriglohn. IAQ Report: 2012/01 (2012)

Kvasnicka, M.: Does temporary help provide a stepping stone to regular employment? NBER Working Paper No. 13843 (2008)

Lehmer, F., Ziegler, K.: Lohndifferenzial Zeitarbeit. 14.04.2011. IAB, Nürnberg (2011)

Lehmer, F., Ziegler, K.: Brückenfunktion der Leiharbeit: Zumindest ein schmaler Steg. IAB Kurzbericht 13 (2010)

Manow, P., Seils, E.: Adjusting badly: The German welfare state, structural change, and the open economy. In: Scharpf, F.W., Schmidt, V.A. (eds.) Welfare and Work in the Open Economy. Diverse Response to Common Challenges, pp. 64-307. Oxford University Press, Oxford (2000)

Mosthaf, A., Schnabel, C., Stephani, J.: Low-Wage Careers: Are There Dead-End Firms and Dead-End Jobs? Zeitschrift für Arbeitsmarktforschung. 43(3), 231-249 (2011)

Osterman, P.: Choice of employment systems in internal labor markets. Ind. Relat. 26(1), 46-67 (1987)

Palier, B., Thelen, K.: Institutionalizing dualism: Complementarities and change in France and Germany. Polit. Soc. 38(1), 119-148 (2010)

Pfeifer, C.: Fixed-term contracts and wages revisited using linked employer-employee data. Z. Arbeitsmarktforschung. 45(2), 171-183 (2012)

Reisenbichler, A., Morgan, K.J.: 'From 'sick man' to 'miracle': Explaining the robustness of the German labor market during and after the financial crisis 2008-09." Polit. Soc. 40(4), 549-579 (2012)

Rinne, U., Zimmermann, K.F.: Another economic miracle? The German labor market and the great recession. IZA. J. Labor. Policy. 1, 1-21 (2011)
Sengenberger, W.: Struktur und Funktionsweise von Arbeitsmärkten. Die Bundesrepublik Deutschland im internationalen Vergleich. Campus Verlag, Frankfurt a. M. (1987)

Spermann, A.: The new role of temporary agency work in Germany. IZA Discussion Paper 6180 (2011)

Streeck, W.: Re-Forming Capitalism. Institutional Change in the German Political Economy. OUP, Oxford (2009)

Voss, D., Weinkopf, C.: Niedriglohnfalle Minijob. WSI Mitteilungen. 65(1), 5-12 (2012)

Wolf, E.: Lohndifferenziale zwischen Vollzeit- und Teilzeitbeschäftigten in Ost- und Westdeutschland. WSI Diskussionspapier 174 (2010)

Werner Eichhorst studied sociology, political science, psychology and public policy and administration at the universities of Tuebingen and Konstanz where he graduated as Diplom-Verwaltungswissenschaftler in 1995. From 1996 to 1999 he was doctoral and post-doctoral fellow at the Max Planck Institute for the Study of Societies in Cologne. In fall 1998 he received his doctoral degree from the University of Konstanz. From 1999 to 2004 he was project director at the Bertelsmann Foundation, a private think tank in Germany, where he was responsible for comparative analyses of the German labor market and related policy areas ("Benchmarking Germany"). After working with the Institute for Employment Research, IAB, from 2004 to 2005, he joined IZA as Research Associate in July 2005, became Senior Research Associate in February 2006, Deputy Director of Labor Policy in April 2007 and Director of Labor Policy Europe in January 2014. His main research area is the comparative analysis of labor market institutions and performance as well as the political economy of labor market reform strategies. He also specializes in different aspects of the future of labor. At IZA he takes care of international and European policy-oriented research activities, addressing in particular EU level employment policies.

Verena Tobsch studied Business Administration at the Otto-vonGuericke University Magdeburg and Free University Berlin where she graduated as Diplom-Kauffrau in 1998. From 1998 to 2001 she worked as Research Associate at the German Institute for Economic Research (DIW Berlin) and Europa-University Viadrina at Frankfurt (Oder). From 2001 to 2004 she was Junior Researcher and CEO of CRIS International $\mathrm{gGmbH}$, a private research institute located in Berlin, Germany and Santa Barbara, California (USA). Verena Tobsch gained experience in quantitative research and lecturing during her employment as Research Associate at the International Institute for Management at University of Flensburg (2006-2008) and at the Institute for HRM and Labour at the Helmut-Schmidt-University in Hamburg (2008-2012). Since 2005 she also works as a freelancer in the field of scientific research and analysis of the German and European labour market, also for IZA. In summer 2014 she received her doctoral degree (Dr. pol.) from Hamburg University and worked for IZA as a Research Assistant from July 2014 until February 2015. Her main research area covers the comparative analysis of labor market institutions and performance as well as working conditions of non-standard employment, work-life-balance and labor force potentials. 